\title{
Impacting Student Perceptions about Careers in Information Systems
}

\author{
Kent A. Walstrom and Thomas P. Schambach \\ IIlinois State University, Normal, IL, USA
}

kawalst@ilstu.edu; tpscham@ilstu.edu

Executive Summary

A shortage of graduates prepared to fill the available jobs in Information Systems remains. Previous studies have verified the shortage and attempted to explain why students do not major in Information Technology related fields. Since prior studies identified lack of awareness regarding the discipline as a major reason in ignoring the major, the purpose of this study is to determine if reading an article about the work of a requirements analyst would positively impact the perceptions of student respondents about careers in Information Systems. It was found that perceptions about careers in Information Systems related fields can be improved by exposing students to the work-life activities of Information Systems professionals. Using a pretest/posttest experimental design, perceptions regarding careers in IS were collected before and after students read Karl Wiegers' article "So You Want to be a Requirements Analyst?" Posttest findings indicate statistically significant positive changes in participant's perceptions about careers in Information Systems related fields, especially related to Systems Analysts roles.

Keywords: Information Systems careers, IT careers, IT workforce, choice of major

\section{Introduction}

Workforce management involves looking forward to the future and planning today for the knowledge and skills that will be needed to enable and sustain envisioned prospects. Such planning and preparation should be important to organizations, nations, and even as a global community in order to facilitate and sustain economic development and prosperity. Planning for IT related skills may be principally important because IT investments are particularly cogent in delivering substantial benefits to businesses and more generally raising the productivity level of knowledge workers (Davenport, 2011; Mithas, Tafti, Bardhan \&Goh, 2012). Correspondingly, the Bureau of Labor Statistics and the Gartner Group predict a shortage of qualified IT professionals throughout the remainder of the decade (Bitterer, Chandler, Gassman, \& Laney, 2011; Morello, 2012; U.S. Bureau of Labor Statistics, 2012) despite the currently subdued economy.

Research indicates a growing concern about the future need for, and corresponding insufficient supply of, professionals in IT related fields. Seventy-five percent of the jobs being created re-

Material published as part of this publication, either on-line or in print, is copyrighted by the Informing Science Institute. Permission to make digital or paper copy of part or all of these works for personal or classroom use is granted without fee provided that the copies are not made or distributed for profit or commercial advantage AND that copies 1) bear this notice in full and 2) give the full citation on the first page. It is permissible to abstract these works so long as credit is given. To copy in all other cases or to republish or to post on a server or to redistribute to lists requires specific permission and payment of a fee. Contact Publisher@InformingScience.org to request redistribution permission. quired specialized technology training, but only 25 percent of the workforce can be described as having such training (Gordon, 2005). In some high profile industries, such as healthcare, IT enabled systems are sought to remedy cost and efficiency issues while also substantially enabling enhanced care (Shein, 2012). Yet, the hoped for breakthroughs in the Healthcare Industry suffers a double whammy with both a shortage of 
Impacting Student Perceptions

trained healthcare professionals and a shortage of health IT professionals (Goedert, 2011). Studying and solving the shortage of healthcare professionals will be left to those in the healthcare discipline. For the purposes of this study, the aspect of IT professional workforce shortage will be addressed.

Universities should endeavor to provide both the quality and quantity of graduates necessary to fill the needs of the future workforce. Declining enrollments in IT fields of study have been identified and investigated for the past several years. Over the past decade, enrollments have been described as having "declined sharply" (Granger, Dick, McKinnell Jacobson, \& Van Slyke, 2007), having "plummeted" (Koch and Kayworth, 2009) and having "plagued" the IT field (Downey, McGaughey, \& Roach, 2009). Having acknowledged the decline in enrollments, research has been conducted to understand "why" students are choosing to avoid studying Information Technology related subjects. A substantial body of knowledge now exists to begin to explain the "why" IT related enrollments have declined. The next step is to apply this existing research in an attempt to increase enrollments and, thus, supply a more robust graduate pipeline corresponding to the demand for IT services and qualifying professionals. One important aspect determined by past research is that incoming students lack interest in the IT area, especially the information systems focus, largely because they know nothing about it (Scott, Fuller, MacIndoe, \& Joshi, 2009; Walstrom, Schambach, Jones, \& Crampton, 2008). The purpose of this study is to determine if reading an article about the work of a requirements analyst will positively impact the perceptions of student respondents about careers in Information Systems, especially in relationship to the role of computer Systems Analysts.

\section{Background Literature}

\section{Interest in Information Technology}

In college, students tend to study subjects that interest them (Galotti, 1999). Previous studies have found that personal interest serves as primary driver in choosing an IT major (Akbulut \& Looney, 2009; Walstrom et al., 2008). Interest is the most important influence for both Management Information Systems majors and Computer Science majors (Downey et al., 2009). The implication is that interest in IT related fields must be created and developed (Downey, McGaughey, \& Roach, 2011).

\section{Lack of Understanding about Careers in Information Technology}

If interest is a primary consideration for selecting a field of study, it is important to have enough knowledge about a field to make an informed determination if one is interested or not. Previous studies have found that college students possess less knowledge about careers in the IT field than other potential careers and are notably unaware of information systems as a major or as a potential career path (Scott et al., 2009; Walstrom et al., 2008). It was also found that high school students have heard of most business majors, such as accounting, marketing, and management, but many were not even aware of management information systems (Downey et al., 2009, 2011). Even when students know what characteristics they want in a career, they do not recognize the opportunities an IT career could offer them (von Hellens, Clayton, Beekhuyzen, \& Nielsen, 2009). On the plus side, students do not entertain misperceptions about careers in IT; they merely lack awareness and understanding (Kuechler, McLeod, \& Simkin, 2009). Such unawareness should be more easily overcome than trying to battle and overcome misperceptions. Nonetheless, it reasons that an awareness and some knowledge of job/career characteristics and associate rewards (outcomes) are a prerequisite to students determining whether a given discipline aligns with their personal values and aptitudes, and thus underlies their interest and potential choice (of 
major, and likely career path). Figure 1 shows the importance of awareness of job or role characteristics on interest in a particular career.

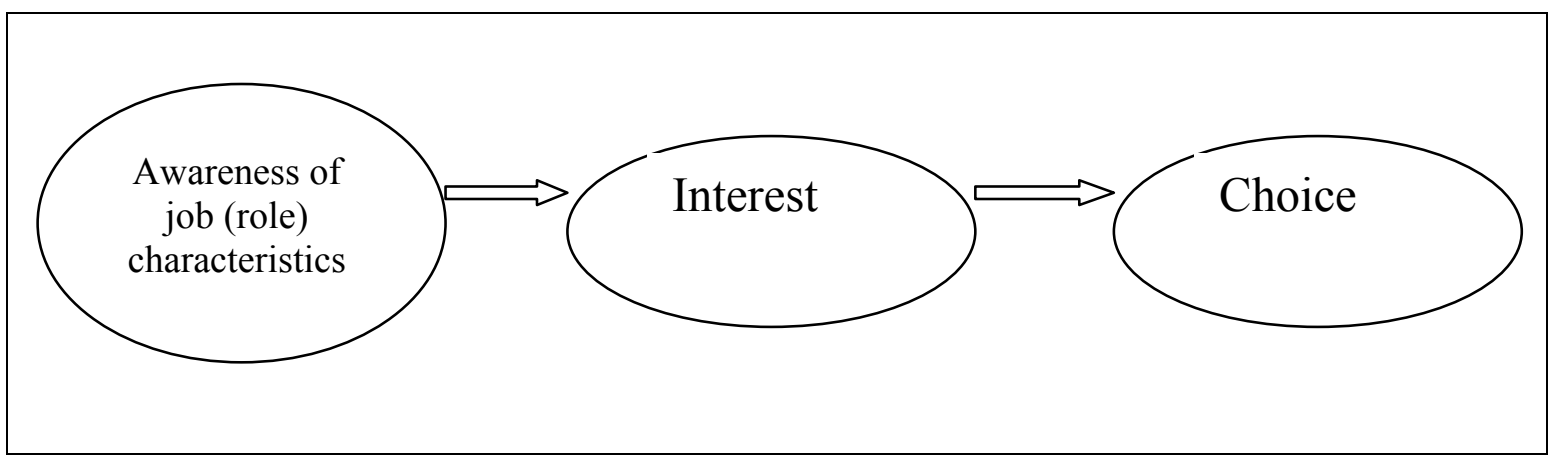

Figure 1. Importance of Awareness on Interest

\section{Providing Understanding about Careers in IT}

Is college too late? Previous research indicates that Computer Science majors are more influenced toward their major prior to college, while Management Information Systems majors are more influenced toward their major during college (Downey et al., 2009). MIS faculty can provide influence more easily during college than they can before or after college. In fact, it has been suggested that using the early MIS college classes to promote interest in IT would be a wise choice (Downey, 2011). A trend was identified where departments are using the core IS course as a means for changing students' perceptions about careers in IT (Granger et al., 2007).

\section{Role Models}

Providing role models has been suggested as one way to change mental models of the IT profession. Bringing students to IT work places to observe IT managers and knowledge workers solving real world problems can make IT careers more attractive to young people, especially women and minorities (Agosto, Gasson, \& Atwood, 2008). The lack of role models is particularly noticeable among women. Along with other science, technology, engineering, and math (STEM) disciplines, IT is often considered a male dominated career presenting yet another barrier for women to overcome who wish to enter the field (Trauth, Nielsen, \& von Hellens, 2003). Females (and students in general) have avoided entering IT fields of study because of the lack of role models (von Hellens et al., 2009).

Role models can be provided in a number of ways. As suggested by the previous studies above, students can actually visit a business and watch IT workers in action. This probably provides the richest information to the observer but comes at a high cost (travel, inconvenience, etc.) and may not always be possible because of workplace availability and associated interference with normal work procedures. Furthermore, a one day time-slice of a professional's activities is likely to be narrowly focused and miss much of the diverse activities in their overall work role.

Guest speakers, video showings, or rich narratives can also serve to portray role models and subsequently influence student perceptions. For example, "forensic science is one of the hottest new majors on college campuses" based largely on recently glamorized role models that young people view via televised video showings (Parker, 2007). Although IT lacks glamorous television serials, bringing in successful IT workers and managers to overview and explain their work can help students to visualize the role and impact of these professionals. Having them convey their work role via descriptive writings or video would enable more wide-spread conveyance of their mes- 
Impacting Student Perceptions

sage. Such narration allows the role model to overview and synthesize a variety of work activities rather than illustrating just a one-day view. For the purposes of this study, a narrative role model was used in order to bring a rich work role description to a broad range of students. Karl Wiegers' article "So You Want to be a Requirements Analyst?" (2003) was selected to serve as a narrative example of the work IT professionals might engage in. More particularly, Wiegers' article depicts the duties, activities and importance of the systems analysts role, an occupational role with substantial need and growth potential according to the Occupational Outlook Handbook Projections (U.S. Bureau of Labor Statistics, 2012).

\section{"So You Want To Be a Requirements Analyst?"}

The article by Karl Wiegers (2003) was selected as representative of the skills and abilities necessary to be a successful IT professional (Systems Analyst), especially within the business school oriented realm of systems analysis, design, and project management. Both technical and nontechnical skills are critical for IT professionals (Gallagher, Kaiser, Simon, Beath, \& Goles, 2010). Business skills, project management skills, and systems analysis and design skills (both technical and client-facing) are important (SIM Advocacy Research Team, 2006). Information design and business process design are considered key to delivering technology enabled solutions (Berry, 2012). In addition, the aspiring IT professional needs problem solving skills (Stevens, Totaro, \& Zhu, 2011). These IT professional skills and abilities were considered to be an adequate representation rather than a comprehensive list, and such skill application is richly portrayed in Wiegers' article.

The article is a five page description of the tasks performed and the skills needed to perform requirements analysis. Wiegers presents ideas related to systems analysis and design, project management, and business process design ideas in the section on The Analyst's Tasks. The article presents ideas on management skills, information design, and problem solving in the section on Soft Skills. The section on Domain, Business and Task Knowledge presents the idea of business knowledge. "So You Want to be a Requirements Analyst?" was deemed to fairly represent the skills and abilities necessary to be a successful IT professional (Systems Analyst) and was selected for use in this study.

\section{Research Questions}

Previous studies have found that interest impacts choice of major and choice of career. Previous research has also found that awareness about the characteristics of a particular job or career impact interest. This study attempts to extend related research by applying a role descriptive intervention in an attempt to impact perceptions and awareness about the characteristics of jobs and roles in the Information Systems field, in particular, the job or role of a computer system requirements analyst. To that end, the following research questions were examined:

1. Can perceptions about careers in Information Systems be positively impacted by reading a role descriptive article (Karl Wiegers' article "So You Want to be a Requirements Analyst?")?

2. Which perceptions about careers in Information Systems can be most positively impacted by reading Karl Wiegers' article "So You Want to be a Requirements Analyst?"

\section{Methodology}

The core MIS overview course in a College of Business at a large Midwestern USA university was used as a sample group. A One-Group Pretest-Posttest design was used for the purposes of this study (Cook \& Campbell, 1979). 


\section{PreTest}

Subjects were given a survey asking them to rate their perceptions about careers in their major and careers in Information Systems for 22 job characteristics. The Pretest survey was administered at the end of the second week of the semester in a controlled classroom setting. The first question on the survey asked participants to identify their major as shown in Figure 2.

\begin{tabular}{|c|c|c|c|c|c|}
\hline 1. What i & your major & one): & Accounting & Business Admin. & Finance \\
\hline Insurance & Marketing & Management & Info. Systems & Other ( & \\
\hline
\end{tabular}

Figure 2. Survey Question \#1

The next 22 questions asked participants to provide perceptions about careers in their major and perceptions about careers in Information Systems using a 7-point Likert-type scale as shown in Figure 3.

For both career paths listed below, please rate each regarding your perceptions of the job characteristics associated with that career path. Please rate each dimension using the following rating scale

$\begin{array}{lllccc}1 & 2 & 3 & 4 & 6 & 7 \\ \text { Very } & \text { Somewhat } & & \text { Neither Positive } & \text { Somewhat } & \text { Very } \\ \text { Negative } & \text { Negative } & & \text { nor Negative } & \text { Positive } & \text { Positive }\end{array}$

Figure 3. Survey 7-Point Likert Scale

\section{Treatment}

Subjects were then instructed to read the article "So You Want to be a Requirements Analyst?" by Karl E. Wiegers (2003). Subjects were allowed to read the article when and where it was convenient for them within a five day time period. They were instructed to take as much time as they needed to read and re-read the article.

\section{Posttest}

Subjects were instructed to self-administer the posttest upon completion of reading the article. The pretest and posttest survey instruments were identical. Participants submitted the completed posttest survey at the beginning of class on the fifth calendar day after taking the pretest.

\section{Results}

A total of 216 usable responses were collected. The first question on the survey asked the participants to identify their current major. As shown in Table 1, ten different majors were represented by the 216 respondents. The largest percentage of respondents 56 ( 25.9 percent) were Finance majors. Accounting, Business Administration, Management and Marketing were each represented by over ten percent of the respondents. Only three Information Systems majors were among the respondents (unfortunately, fairly representative of the dearth of IS majors within the business school at this university). 
Table 1. Respondents By Major

\begin{tabular}{|l|c|c|}
\hline & FREQUENCY & PERCENT \\
\hline Accounting & 37 & 17.1 \\
\hline Business Administration & 33 & 15.3 \\
\hline Business Teacher Education & 7 & 3.2 \\
\hline Entrepreneurship & 2 & 0.9 \\
\hline Finance & 56 & 25.9 \\
\hline Information Systems & 3 & 1.4 \\
\hline Insurance & 7 & 3.2 \\
\hline International Business & 3 & 1.4 \\
\hline Management & 29 & 13.4 \\
\hline Marketing & 39 & 18.1 \\
\hline TOTAL & 216 & 100 \\
\hline
\end{tabular}

Table 2 shows the respondents Pretest perceptions related to careers in their majors and careers in Information Systems. All perceptions on all questions for careers in their majors and careers in Information Systems were rated positively. No averages were below 4, which was labeled as "Neither Positive nor Negative." Numbers 1 through 3 were identified as negative perceptions, while numbers 5 through 7 represented progressively more positive perceptions. Overall, respondent's pre-existing perceptions about careers in both their major and careers in Information Systems were positive. Nonetheless, relatively weaker ratings for IS careers on several important items were reported, such as: Job Satisfaction, Prestige, Working with clients, Working with team mates, Office environment, and Opportunity for social interaction. 
Table 2. Pretest Results For All Respondents

\begin{tabular}{|l|c|c|}
\hline QUESTION & $\begin{array}{l}\text { Careers in your } \\
\text { major: }\end{array}$ & $\begin{array}{l}\text { Careers in Information } \\
\text { Systems }\end{array}$ \\
\hline 2. Job availability & 5.34 & 5.49 \\
\hline 3. Job Security & 5.08 & 5.07 \\
\hline 4. Starting Pay and Benefits & 5.04 & 5.01 \\
\hline 5. Promotion Opportunities & 5.70 & 5.24 \\
\hline 6. Career Longevity & 5.98 & 5.48 \\
\hline 7. Job Satisfaction & 5.67 & 4.95 \\
\hline 8. Prestige & 5.58 & 5.02 \\
\hline 9. Working with clients & 5.99 & 4.60 \\
\hline 10. Working with team mates & 5.92 & 5.05 \\
\hline 11. Working with numbers & 5.72 & 5.39 \\
\hline 12. Opportunities to travel & 5.45 & 4.51 \\
\hline 13. Opportunities for professional development & 5.98 & 5.55 \\
\hline 14. Geographic location & 5.57 & 5.09 \\
\hline 15. Office environment & 5.56 & 4.87 \\
\hline 16. Structured assignments & 5.45 & 5.20 \\
\hline 17. Flexible work schedule & 4.70 & 4.89 \\
\hline 18. Opportunity to be innovative & 5.15 & 5.94 \\
\hline 19. Professional image & 6.23 & 5.36 \\
\hline 20. Interesting work assignments & 5.53 & 5.31 \\
\hline 21. Opportunity for social interaction & 6.02 & 4.75 \\
\hline 22. Opportunity to work with new technologies & 6.05 & \\
\hline 23. Long-term pay and benefits & & \\
\hline
\end{tabular}

Table 3 shows the respondents Posttest perceptions related to careers in their majors and careers in Information Systems. The Posttest used the same 7-point scale. No averages were below 4, which was labeled as "Neither Positive nor Negative." Numbers 1 through 3 were identified as negative perceptions. Overall, respondent's perceptions about careers in their major and careers in Information Systems were both still positive after reading the assigned article. Importantly, the intervention (reading assignment) spawned a substantial improvement in business student perceptions about IS careers. 
Table 3. Posttest Results for All Respondents

\begin{tabular}{|l|c|c|}
\hline & $\begin{array}{l}\text { Careers in your } \\
\text { major: }\end{array}$ & $\begin{array}{l}\text { Careers in Information } \\
\text { Systems }\end{array}$ \\
\hline 2. Job availability & 5.43 & 5.72 \\
\hline 3. Job Security & 5.34 & 5.56 \\
\hline 4. Starting Pay and Benefits & 5.22 & 5.36 \\
\hline 5. Promotion Opportunities & 5.73 & 5.59 \\
\hline 6. Career Longevity & 5.90 & 5.74 \\
\hline 7. Job Satisfaction & 5.67 & 5.37 \\
\hline 8. Prestige & 5.69 & 5.46 \\
\hline 9. Working with clients & 5.94 & 5.18 \\
\hline 10. Working with team mates & 5.80 & 5.58 \\
\hline 11. Working with numbers & 5.84 & 5.72 \\
\hline 12. Opportunities to travel & 5.44 & 5.03 \\
\hline 13. Opportunities for professional development & 5.97 & 5.81 \\
\hline 14. Geographic location & 5.58 & 5.40 \\
\hline 15. Office environment & 5.68 & 5.40 \\
\hline 16. Structured assignments & 5.57 & 5.63 \\
\hline 17. Flexible work schedule & 4.85 & 5.16 \\
\hline 18. Opportunity to be innovative & 5.25 & 5.98 \\
\hline 19. Professional image & 6.18 & 5.60 \\
\hline 20. Interesting work assignments & 5.56 & 5.62 \\
\hline 21. Opportunity for social interaction & 5.95 & 5.12 \\
\hline 22. Opportunity to work with new technologies & 5.96 & \\
\hline 23. Long-term pay and benefits & & 58 \\
\hline
\end{tabular}

\section{Careers in Information Systems}

Table 4 compares participants' responses on the Pretest and the Posttest relative to IS careers. Also shown is the difference between perceptions from the Pretest to the Posttest and the statistical significance of those differences. For all 22 questions, respondent perceptions were more positive about careers in Information Systems after reading "So You Want to be a Requirements Analyst?" Nineteen of the 22 differences were significant at the 0.01 level. One difference was significant at the 0.1 level. The differences on the remaining two questions were positive, but not statistically significantly so, but were also on items where IS careers already ranked very high on the pretest and then again on the posttest. 
Table 4. Pretest-Posttest Comparisons of Perceptions about Careers in Information Systems by Greatest Positive Change in Perception

\begin{tabular}{|l|c|c|c|c|}
\hline QUESTION AREA & $\begin{array}{l}\text { PRETEST } \\
\text { Perceptions }\end{array}$ & $\begin{array}{l}\text { POSTTEST } \\
\text { Perceptions }\end{array}$ & Differences & Significance \\
\hline 21. Opportunity for social interaction & 4.52 & 5.12 & 0.58 & $.000^{* * *}$ \\
\hline 9. Working with clients & 4.60 & 5.18 & 0.53 & $.000^{* * *}$ \\
\hline 10. Working with team mates & 5.05 & 5.58 & 0.53 & $.000^{* * *}$ \\
\hline 15. Office environment & 4.87 & 5.40 & 0.51 & $.000^{* * *}$ \\
\hline 12. Opportunities to travel & 4.51 & 5.03 & 0.50 & $.000^{* * *}$ \\
\hline 3. Job Security & 5.07 & 5.56 & 0.49 & $.000^{* * *}$ \\
\hline 8. Prestige & 5.02 & 5.46 & 0.44 & $.000^{* * *}$ \\
\hline 16. Structured assignments & 5.20 & 5.63 & 0.43 & $.000^{* * *}$ \\
\hline 7. Job Satisfaction & 4.95 & 5.37 & 0.39 & $.000^{* * *}$ \\
\hline 5. Promotion Opportunities & 5.24 & 5.59 & 0.32 & $.000^{* * *}$ \\
\hline $\begin{array}{l}\text { 22. Opportunity to work with new tech- } \\
\text { nologies }\end{array}$ & 6.61 & 6.92 & 0.31 & .334 \\
\hline 4. Starting Pay and Benefits & 5.01 & 5.36 & 0.30 & $.000^{* * *}$ \\
\hline 11. Working with numbers & 5.39 & 5.72 & 0.30 & $.000^{* * *}$ \\
\hline 6. Career Longevity & 5.48 & 5.74 & 0.29 & $.000^{* * *}$ \\
\hline 20. Interesting work assignments & 5.31 & 5.62 & 0.29 & $.002^{* * *}$ \\
\hline 19. Professional image & 5.36 & 5.60 & 0.26 & $.001^{* * *}$ \\
\hline 17. Flexible work schedule & 4.89 & 5.16 & 0.25 & $.003^{* * *}$ \\
\hline 2. Job availability & 5.49 & 5.72 & 0.24 & $.002^{* * *}$ \\
\hline $\begin{array}{l}\text { 13. Opportunities for professional devel- } \\
\text { opment }\end{array}$ & 5.55 & 5.81 & 0.24 & $.000^{* * *}$ \\
\hline 14. Geographic location & 5.09 & 5.40 & 0.24 & $.001^{* * *}$ \\
\hline 23. Long-term pay and benefits & 5.75 & 5.88 & 0.10 & $.078^{*}$ \\
\hline 18. Opportunity to be innovative & 5.94 & 5.98 & 0.03 & .726 \\
\hline Signicat a the 0.1 leve & & & & \\
\hline
\end{tabular}

Significant at the 0.1 level $=*$

Significant at the 0.05 level $=* *$

Significant at the 0.01 level $=* * *$

\section{Findings}

One important finding from Table 4 is the positive change in perception regarding working with other people. The top positive changes were related to these three areas: \#21. Opportunity for social interaction, \#9. Working with clients, and \#10. Working with team mates. It appears that prior to reading the article respondents viewed Information Systems careers as non-interactive. Such a misinformed view on these important social job aspects may be particularly deterring to a generation that thrives on their social networking and being connected. Interventions that alter their view to awareness of socially active analysts' roles may help in attracting enhanced enrollments.

\section{Differences between Careers in Your Major and Careers in IS}

Table 5 shows differences in respondent perceptions between careers in their major and careers in Information Systems. On the Pretest, respondents perceived careers in Information Systems to be 
less positive than careers in their major for 18 of the 22 questions. On four questions, careers in Information Systems were initially perceived to be more positive than careers in their major. On the Posttest, respondents perceived careers in Information Systems to be less positive than careers in their major for 14 of the 22 questions. But on eight questions, careers in Information Systems were perceived to be more positive than careers in their major. Moreover, on all but one question, post-reading perceptions of careers in Information Systems improved when compared with careers in their major. For that question, Opportunity to be innovative, perceptions declined slightly but from a relatively high base. These findings suggest that obtaining more information about the IT work role (via a narrative reading intervention) was successful in positively impacting perceptions regarding IT careers, especially in regards to informing students regarding the social interaction aspects within the requirements analyst role.

\section{Table 5. Changes in Perceptions between Careers in Your Major and Information Systems Careers by Order of Change}

\begin{tabular}{|l|c|c|c|}
\hline QUESTION & $\begin{array}{l}\text { PRETEST differ- } \\
\text { ences in percep- } \\
\text { tions between } \\
\text { careers }\end{array}$ & $\begin{array}{l}\text { POSTTEST dif- } \\
\text { ferences in per- } \\
\text { ceptions between } \\
\text { careers }\end{array}$ & $\begin{array}{l}\text { Positive / Nega- } \\
\text { tive Change }\end{array}$ \\
\hline 21. Opportunity for social interaction & -1.50 & -0.83 & +0.67 \\
\hline 10. Working with team mates & -0.87 & -0.22 & +0.65 \\
\hline 9. Working with clients & -1.39 & -0.76 & +0.63 \\
\hline 12. Opportunities to travel & -0.94 & -0.41 & +0.53 \\
\hline 7. Job Satisfaction & -0.72 & -0.30 & +0.42 \\
\hline 15. Office environment & -0.69 & -0.28 & +0.41 \\
\hline 6. Career Longevity & -0.50 & -0.16 & +0.34 \\
\hline 8. Prestige & -0.56 & -0.23 & +0.33 \\
\hline 5. Promotion Opportunities & -0.46 & -0.14 & +0.32 \\
\hline 16. Structured assignments & -0.25 & +0.06 & +0.31 \\
\hline 14. Geographic location & -0.48 & -0.18 & +0.30 \\
\hline 19. Professional image & -0.87 & -0.58 & +0.29 \\
\hline $\begin{array}{l}\text { 13. Opportunities for professional develop- } \\
\text { ment }\end{array}$ & -0.43 & -0.16 & +0.27 \\
\hline 20. Interesting work assignments & -0.22 & +0.04 & +0.26 \\
\hline 3. Job Security & -0.01 & +0.22 & +0.23 \\
\hline 23. Long-term pay and benefits & -0.30 & -0.08 & +0.22 \\
\hline 11. Working with numbers & -0.33 & -0.12 & +0.21 \\
\hline 4. Starting Pay and Benefits & -0.03 & +0.14 & +0.17 \\
\hline $\begin{array}{l}\text { 22. Opportunity to work with new technolo- } \\
\text { gies }\end{array}$ & +1.36 & +1.51 & +0.15 \\
\hline 2. Job availability & +0.15 & +0.29 & +0.14 \\
\hline 17. Flexible work schedule & +0.19 & +0.31 & +0.12 \\
\hline 18. Opportunity to be innovative & +0.79 & +0.74 & -0.05 \\
\hline
\end{tabular}

\section{Conclusions}

All participants in the study were either juniors or seniors, and most were seniors since the MIS overview course is often taken late in students' program of study (not a prerequisite for any other course). Correspondingly, it is not surprising that most respondents still rated their major favorably on the posttest survey. Nonetheless, it is impressive that merely the opportunity to learn about 
common elements of the requirements analyst role was sufficient to significantly, positively impact most students perceptions regarding IT on most job characteristics referenced on the questionnaire. For eight of the 22 characteristics they actually developed more positive perceptions of IT roles than they had relative to their own major.

Findings of this study suggest exposure to rich, descriptive information about careers in IT can significantly, positively impact the perceptions of students. Using Wiegers' role descriptive article (2003) "So You Want to be a Requirements Analyst?" as a narrative role model served as a catalyst for such perception enhancement. After reading the article, respondents' perceptions about careers in IT were significantly, positively impacted for 20 out of 22 questions related to career perceptions.

Even a small exposure to the skills, abilities, and work activities required of an IT professional can impact a large number of preconceived perceptions in a positive manner. Wiegers article weighs in at five pages with just over 2000 words and one figure, yet it was able to positively change perceptions about careers in IT on 20 areas including such things as working with people, job satisfaction, work environment, compensation and benefits, and lifestyle.

Findings suggest that the information about IT careers does not have to be extensive or complicated to impact perceptions. In fact, frequent short exposures to smaller chunks of information might be more beneficial. This would provide opportunities for reinforcement of perceptions. However, conclusive evidence along these lines will require further research.

For example, an academic program that includes a general business career overview or an MIS course early in the curriculum might assign reading or exposure paralleling the Wiegers article and then evaluate whether there are any notable changes in IT career interest, enrollment plans, or actual enrollment outcomes.

Perceptions about careers in Information Systems related fields can and should be significantly, positively impacted by exposure to examples of the skills and abilities used by these professionals. Real world IT workers are ranked among the most satisfied of all career areas (Laudon, 2011); successful interventions would find a way of sharing this knowledge with new students. Successfully building knowledge and awareness of the job characteristics of IS work roles, if in alignment with student valued characteristics, may help to establish interest in and ultimately enrollment in IT related disciplines.

\section{Limitations and Future Research}

Similar to many studies in IS and the social sciences this study applies parametric analysis to scaled ordinal responses. While statistical purist may take issue with this approach, Nunnally $(1978$, p.17) argues this approach is generally permissible.

Future studies should include a control mechanism to ensure adequate understanding of the information presented in the treatment article. There was no control to ensure that all subjects thoroughly read the Wiegers' article. Thus, the significant positive impact on overall perceptions was obtained despite the possibility of only a partial treatment. A quiz or reflection paper could be required as a control mechanism. Future studies may also want to incorporate additional instruments to first profile student values and aptitudes and then evaluate whether there is an interactive impact in determining potential changes in student IT career interests and potential enrollment in the major.

Future studies should include the use of different types of treatments to determine the characteristics of activities and experiences which will provide the greatest positive impact on perceptions about careers in Information Systems. The use of longer articles and books should be considered, or perhaps a series of YouTube videos illustrating the IT worker in action. The administration of 
pretest and posttest survey should also be considered for use in conjunction with field trips, guest speakers, and internships.

Future studies should include the use of posttest treatments at longitudinal intervals. Subjects could be re-examined after one-semester and at the end of their college career or at other suitable intervals. This examination could be used to determine the duration and long-term impact of the treatments used to impact perceptions about careers in Information Systems.

Future studies should make greater efforts to recruit and examine subjects who have selected majors which will prepare them for careers in Information Systems. A large pool of Information Systems career oriented majors would allow for the establishment of baseline perceptions about careers in Information Systems by those who already have favorable perceptions prior to any controlled treatments.

Future studies should address other career paths in Information Technology field besides Systems Analysts. Wieger's article depicts the role of requirements analysts within a business context. A variety of other career paths should be examined such as computer programming, database administration, network administration, and cyber security.

Future studies should examine the impact on perceptions of different populations. The subjects of this study were business students and their perceptions were significantly enhanced in the posttest survey. It is possible that the same intervention may have a differing impact, or no impact, on a subject pool where there is no pre-existing interest in business studies. Evaluations should be conducted on a more diverse population to evaluate whether non-business majors can be influenced by a role-descriptive article that is business context focused.

\section{References}

Agosto, D., Gasson, S., \& Atwood, M. (2008). Changing mental models of the IT professions: A theoretical framework. Journal of Information Technology Education, 7, 205-221. Retrieved from http://www.jite.org/documents/Vol7/JITEv7p205-221Agosto323.pdf

Akbulut, A., \& Looney, C. (2009). Improving IS student enrollments: Understanding the effects of IT sophistication in introductory IS courses. Journal of Information Technology Education, 8, 87-100. Retrieved from http://www.jite.org/documents/Vol8/JITEv8p087-100Akbulut297.pdf

Berry, D. (2012). IT workforce: The road to 2016 and beyond. Gartner Report G00230651, 31 January 2012.

Bitterer, A., Chandler N., Gassman, B., \& Laney, D. (2011). Predicts 2012: Skills gap is the biggest challenge in leveraging new opportunities in analytics and performance management. Gartner Report G00226089, 14 December 2011.

Cook, T., \& Campbell, D. (1979). Quasi-experimentation: Design \& analysis issues for field settings. Boston: Houghton Mifflin Company.

Davenport, T. (2011). Rethinking knowledge work: A strategic approach. McKinsey Quarterly, 1(11). Retrieved April 15, 2012 from http://www.mckinseyquarterly.com/Rethinking knowledge_work_A strategic approach 2739

Downey, J. (2011). An empirical examination of the composition of vocational interest in business colleges: MIS vs. other majors. Journal of Information Systems Education, 22(2), 147-158.

Downey, J., McGaughey, R., \& Roach, D. (2009). MIS versus computer science: An empirical comparison of the influences on the students' choice of major. Journal of Information Systems Education, 20(3), 357-368.

Downey, J., McGaughey, R., \& Roach, D. (2011). Attitudes and influences toward choosing a business major: The case of information systems. Journal of Information Technology Education, 10, 231-251. 
Galotti, K. (1999). Making a "major" real-life decision: College students choosing an academic major. Journal of Educational Psychology, 91(2), 379-387

Gallagher, K., Kaiser, K., Simon, J., Beath, C., \& Goles T. (2010). The requisite variety of skills for IT professionals. Communications of the ACM, 53(6), 144-148.

Goedert, J. (2011) Tackling the health I.T. workforce shortage. Health Data Management, 19(2), 40-47.

Gordon, E. (2005). The 2010 meltdown: Solving the impending jobs crisis. Westport, CT: Praeger Publishers.

Granger, M., Dick, G., McKinnell Jacobson, C., \& Van Slyke, C. (2007). Information systems enrollments: Challenges and strategies. Journal of Information Systems Education, 18(3), 303-311.

Koch, H., \& Kayworth, T. (2009). Partnering with the majors: A process approach to increasing IS enrollment. Journal of Information Systems Education, 20(4), 439-449.

Kuechler, W., McLeod, A., \& Simkin, M. (2009). Filling the pipeline for IS professionals: What can IS faculty do? Journal of Information Systems Education, 20(4), 407-418.

Laudon, K. (2011). Occupational and career outlook for MIS majors 2012-2018. Retrieved June 26, 2012, from http://www.uncg.edu/bae/MIS_Outlook_2012-2018.pdf

Mithas, S., Tafti, A., Bardhan, I., \& Goh, J. (2012). Information technology and firm profitability: Mechanisms and empirical evidence. Management Information Systems Quarterly, 36(1), 205-224.

Morello, D. (2012). IT professional outlook, 2012 to 2016: Prepare for future unlike the past. Gartner Report 27 January 2012.

Nunnally, J. (1978). Psychometric theory, (2nd ed.). New York: McGraw-Hill.

Parker, L. (2007, August 27). Students clue into forensic science. USA Today. Retrieved June 26, 2012, from http://usatoday.com/news/education/2007-08-27-forensics-school_N.htm

Scott, C., Fuller, M., MacIndoe, K., \& Joshi, K. (2009). More than a bumper sticker: The factors influencing information systems career choices. Communications of the Association for Information Systems, 24(2), 7-26.

Shein, E. (2012, April 4). Data analytics driving medical breakthroughs. Computerworld. Retrieved April 15,2012 , from http://www.computerworld.com/s/article/9225766/Data_analytics_driving_medical_breakthroughs

SIM Advocacy Research Team. (2006). The information technology workforce: Trends and implications 2005-2008. MISQ-E, 5(2), 47-55.

Stevens, D., Totaro, M., \& Zhu, Z. (2011). Assessing IT critical skills and revising the MIS curriculum. Journal of Computer Information Systems, 51(3), 85-95.

Trauth, E., Nielsen, S., \& von Hellens, L. (2003). Explaining the IT gender gap: Australian stories for the new millennium. Journal of Research and Practice in Information Technology, 35(1), 7-20.

U.S. Bureau of Labor Statistics (2012), Occupational outlook handbook: Projections overview. Retrieved April 13, 2012, from http://www.bls.gov/ooh/About/Projections-Overview.htm

von Hellens, L., Clayton, K., Beekhuyzen, J., \& Nielsen, S. (2009). Perceptions of ICT careers in German schools: An exploratory study. Journal of Information Technology Education, 8, 211-228. Retrieved from http://www.jite.org/documents/Vol8/JITEv8p211-228vonHellens716.pdf

Walstrom, K., Schambach, T., Jones, K., \& Crampton, W. (2008). Why are students not majoring in information systems? Journal of Information Systems Education, 19(1), 43-54.

Wiegers, K. (2003). So you want to be a requirements analyst? Originally published in Software Development, 11(7). Reprinted with modifications with permission from Software Development magazine at http://www.processimpact.com/articles/be analyst.pdf 


\section{Biographies}

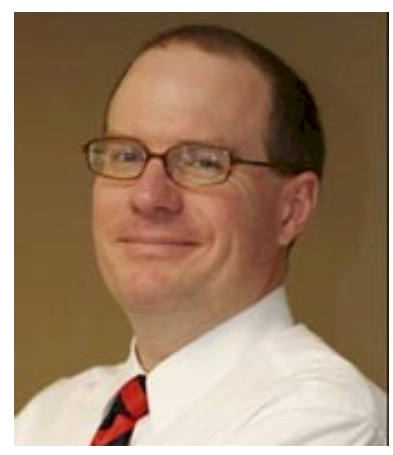

Kent A. Walstrom is an Associate Professor of Information Systems at Illinois State University. Kent's primary teaching area is business information systems. His research interests focus on Executive Information Systems, Electronic Commerce, Leadership Support Systems, and Creativity and Problem Solving. He has published articles in Communications of the ACM, Information \& Management, Journal of Computer Information Systems, Journal of Information Systems Management, Computers \& Operations Research and other journals. Kent has presented and published papers at regional, national, and international information systems conferences.

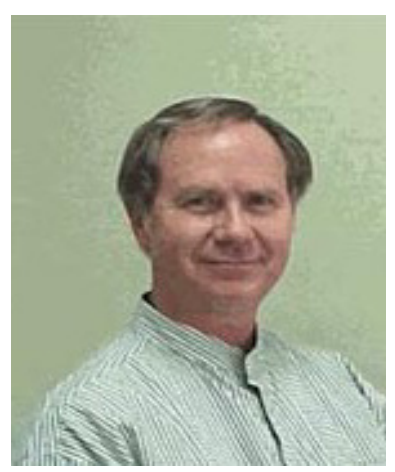

Thomas P. Schambach is an Associate Professor of Information Systems at Illinois State University. Tom's primary teaching areas are database, systems analysis, and management information systems. Before entering academic life he worked as a business analyst, consultant, and project manager for Unisys. His research focuses on Information Technology Workforce issues such as professional development, skill needs, professional motivation, and student internship outcomes. Dr. Schambach has presented and published papers at regional, national and international information systems conferences. He has published articles in Communications of the ACM, Computer Personnel, Journal of Computer Information Systems and Journal of Information Systems Education and other journals. 